\title{
Implementing CA-T Model Lessons in Schools: A Preliminary Study in Southern Border Provinces of Thailand
}

\author{
Kemtong Sinwongsuwat ${ }^{1} \&$ Kathleen Nicoletti ${ }^{2}$ \\ ${ }^{1}$ Faculty of Liberal Arts, Prince of Songkla University, Thailand \\ ${ }^{2}$ Women's Center, Sayulita, Mexico \\ Correspondence: Kemtong Sinwongsuwat, Department of Foreign Languages, Faculty of Liberal Arts, Prince of \\ Songkla University, Songkhla, Thailand.
}

Received: September 25, 2020

Accepted: October 10, 2020

Online Published: October 16, 2020

doi: 10.5539/elt.v13n11p15

URL: https://doi.org/10.5539/elt.v13n11p15

\begin{abstract}
Encouraged by previous studies which recommended incorporating insights from Conversation Analysis (CA) into English conversation teaching to improve EFL students' oral proficiency, this paper reports on the findings from Phase I of a longitudinal study designed to investigate the impact of employing a CA-informed teaching (CA-T) model to improve Thai students' oral English proficiency. The aim of Phase I of this study was to engage local teachers in co-developing and piloting the CA-T model. In this phase, 16 purposively sampled primary and secondary English teachers from Thailand's southern provinces participated in an intensive 6-day workshop designed to (1) familiarize them with the instructional value of CA insights and key features of the CA-T model and (2) assist these teachers in creating CA-T lesson plans. Following the workshop, teachers piloted the lesson plans, provided feedback on the implementation process, reported on the perceived effects of the lessons, and offered recommendations for improving the CA-T model. This paper describes the content of the workshop, shares teachers' feedback about the CA-T lessons and implementation process, and presents preliminary findings as to the potential challenges and benefits of employing the CA-T model in Thai primary and secondary classrooms.
\end{abstract}

Keywords: Conversation Analysis (CA)-informed instruction, conversation teaching models, EFL learners, English conversation teaching, explicit language teaching, speaking skills

\section{Introduction}

The level of English proficiency of a nation's citizens has become a critical factor in determining its economic competitiveness and global success. This is especially true in developing countries such as Thailand, a member of the powerful economic alliance, the ASEAN Economic Community (AEC), in which English has been adopted as the de facto working and official language. However, despite a multitude of educational reforms and initiatives aimed at improving the English proficiency of Thai students, Thais continue to lag behind their Asian counterparts, particularly in oral English (see Atagi, 2011; Bruner, Shimray \& Sinwongsuwat, 2014; Educational Testing Service (ETS), 2017; EF Education First, 2019; Fredrickson, 2015; Khamkhien, 2010; Mala, 2016, 2019; Nation, 2017; Noom-ura, 2013; Prapphal, 2001). Consequently, foremost among Thai educational reforms has been a nationwide pedagogical shift away from the use of traditional grammar-based and rote-memory approaches in language teaching and toward a Communicative Language Teaching approach (CLT) that promotes the use of meaning-focused and learner-centered activities. The hope among reformers has been that CLT-informed instruction might better aid students in developing communicative competence (Darasawang, 2007; Kustati, 2013; Kwangsawad \& Yawongsa, 2009; Saengboon, 2002), something teacher-fronted approaches have been found to be ineffective at doing (Brown, 1994, 2000; Richards, 2006; Richards \& Rodgers, 2001).

With genuine communication being the central goal of lessons, the use of CLT is believed to help language learners communicate more effectively in real-life situations. Implementing this approach, teachers are encouraged to tolerate errors that do not obstruct meaning and to shift their role as instructors to that of facilitators. Moving away from traditional, teacher-fronted classrooms, the main responsibility of CLT teachers is to create interactive activities (i.e., information gaps, roleplays, etc.) that are thought to promote the development of communicative competence (Brown, 2000; Larsen-Freeman, 1986; Ramadan, 2017). CLT has been widely promoted in Thai schools' foreign language curricula for several decades and has become one of the 
most popular and widely endorsed ELT approaches in Thailand (Baker \& Jarunthawatchai, 2017; Darasawang, 2007; Kustati, 2013; Kwangsawad \& Yawongsa, 2009; Methitham \& Chamcharasti, 2011; Saengboon, 2002, ThaiLIS, 2017, cited in Sinwongsuwat, Nicoletti \& Teng, 2018).

Findings from a number of studies have, however, called into question the effectiveness of the CLT approach in the Thai context (Sinwongsuwat, Nicoletti \& Teng, 2018). Bruner, Sinwongsuwat and Shimray (2014) and Bruner, Sinwongsuwat and Radić-Bojanić (2015) have, in particular, asserted that Thai students'overdependence on information-sharing group activities, preference for group over individual assessments, and teachers' reliance on unrealistic, scripted activities in CLT classrooms have all, to greater and lesser extents, hindered students' ability to be active, independent learners capable of spontaneous interaction in the target language. Moreover, most students' preference for assuming a more passive role in language learning and unfavorable attitudes towards CLT has presented major hindrances in its implementation (Saengboon, 2002).

These findings have led to a recommendation of adopting a more contextualized teaching framework, one which might better address the challenges presented in a teacher's particular context (Alexio, 2003; Saengboon, 2002). This recommendation was echoed by Bax (2003) who argued that those implementing CLT in an EFL context often neglected to account for factors within the local context that can render the approach problematic. These factors have been cited as including teachers' lack of adequate training and support, heavy workload, large class sizes, inadequate resources, and the negative washback effects of national exams (Baker \& Jarunthawatchai, 2017; Bax, 2003; Hayes, 2010; Methitham \& Chamcharasti, 2011; Teng \& Sinwongsuwat, 2015a; Sinwongsuwat, Nicoletti \& Teng, 2018).

Despite its implementation problems and seeming lack of success in increasing the English proficiency level of students, CLT continues to be widely promoted in Thailand. While acknowledging that every teaching approach has its limitations, a number of Thai researchers and educators have argued that since there is no method that fits all, it is probably wiser to opt for an approach that incorporates methods and techniques suitable for local teaching circumstances (see Teng \& Sinwongsuwat, 2015a; Sinwongsuwat, Nicoletti \& Teng, 2018). With this in mind, researchers have begun to consider other instructional approaches to supplement current CLT-based instructional materials and strategies. Many are turning towards the integration of other sociocultural/interactional approaches to enhance CLT (Kirkpatrick \& Ghaemi, 2011; Kramsch, 2014; Kustati, 2013; Sun, 2014; Wu, 2013; Young, 1999) with a number of studies in Thailand suggesting that CLT could be more effective if aspects of Conversation Analysis (CA) were incorporated into CLT-informed English lessons (Choopool \& Sinwongsuwat, 2017; Sinwongsuwat, Nicoletti \& Teng, 2018; Sitthikoson \& Sinwongsuwat, 2017; Teng \& Sinwongsuwat, 2015a; Waedaoh \& Sinwongsuwat, 2018).

\subsection{Conversation Analysis (CA)}

Originating in sociology, Conversation Analysis (CA) owes credit to Harvey Sacks, Emanuel A. Schegloff, and Gail Jefferson, whose groundbreaking research and subsequent publications introduced a discipline that could rigorously and formally deal with the most ubiquitous form of human interaction, everyday conversation (see Sacks, 1995; Sacks, Schegloff, \& Jefferson, 1974; Schegloff \& Sacks, 1973). CA aims to understand and explicate the social order and structure embedded in naturally-occurring talk in conversation and in any other form of interaction that constitutes an integral part of human social life (Duranti, 1997; Have, 2007; Heap, 1997; Hutchy \& Woofit, 1998; Psathas, 1995; Seedhouse, 2004; Sidnell, 2010; Sidnell \& Stivers, 2012).

Inspired by Goffman's focus on face-to-face interaction and influenced by Garfinkel's work in exploring group members' common sense practices in constructing social reality, CA has become the basis of the study of talk-in-interactions, interactions through which social affairs are methodically organized and social actions are orderly accomplished (Liddicoat, 2007; Seedhouse, 2004). Underscored in Seedhouse (2005), CA's main principles are:

1) Conversation, or any talk-in-interaction, is highly ordered and the order can be found at any point in the interaction.

2) Contributions to the interaction are context-shaped and context-building. While these contributions can only be fully comprehended with reference to the preceding sequential context in which they are designed to appear by talk participants, they, at the same time, set the context for interpreting other interactional contributions that follow.

3) No interactional details can be disregarded a priori as disorderly, accidental, or irrelevant (Heritage, 1984). CA is thus highly empirical and adopts a fine-grained transcription system.

4) Analysis of talk is bottom-up and data driven. Prior theoretical assumptions on social concepts/categories 
such as class, ethnicity, gender, and values are only oriented to when there is evidence to prove that the participants themselves are orienting to these categories in interaction details represented in the transcript.

Talk-in-interaction, which involves turn-taking, is the essence of CA (Hutchby \& Wooffitt, 2008). Other practices involved in interactional organization include sequencing practices, preference organization, topic management practices, and repair. For a more detailed account of CA methodology, its data treatment, and theoretical underpinnings, readers may refer to Psathas (1995), Liddicoat (2007), Have (2007), Hutchby and Wooffitt (2008), Sidnell (2010), as well as Wong and Waring (2010).

While CA has been applied in various disciplines beyond sociology, only in the early 2000s has it been taken up in applied disciplines such as interactional and applied linguistics (Couper-Kuhlen \& Selting, 2001; Koshik, Jacoby, Olsher, \& Schegloff, 2002). Seedhouse (2008) and Sert and Seedhouse (2011), assert that CA's fundamental concern with language as action suggests a natural link with applied linguistics. They assert that CA can play an important role in language teaching by applying its resources to different domains of research and practices, e.g. the reflexive relationship between pedagogy (task-as-work plan) and interaction (task-in-process), the organization of classroom interaction, learning assessment, and conversation teaching and learning (Koshik et al., 2002; Pourhaji \& Alavi, 2015; Seedhouse, 2008; Sert \& Seedhouse, 2011).

\subsection{CA-Informed L2 Teaching}

Just as explicit grammatical knowledge is indispensable to understanding how language works phonetically, morphologically and syntactically, explicit knowledge of interactional practices involved in constructing conversation is also necessary for teaching and conversing skillfully in a second language (cf. Wong \& Waring, 2010). CA transcription of genuine talk-in-interaction in various contexts can help learners become aware of the features of spoken language and turn-taking practices. This, coupled with an understanding of sequencing practices in organizing a conversation in the target language, can assist students in learning to effectively get into, maintain, and get out of a conversation. Knowledge of repair practices can also help learners by making them aware of common communicative problems that occur in genuine conversation and equip the learners with the ability to effectively deal with these problems.

Apart from its instructional benefits, CA can be employed to diagnose problems learners encounter during a classroom interaction. While researchers in medical science have recently turned to CA to improve their diagnosis of patients with dementia (Kindell, J., Keady, J., Sage, K., \& Wilkinson, R., 2017), those in applied CA have long claimed that CA holds even greater promise for research into various aspects of classroom-talk-in-interaction, including problems experienced in its dynamic micro-contexts (Sert \& Seedhouse, 2011). CA has been shown to serve as a method for identifying and explaining difficulties experienced by learners as they navigate through these contexts to become more competent L2 speakers (Bowles, 2006). Barraja-Rohan (2011) and Fujii (2012) concur that CA is a powerful tool not only to analyze L2 talk-in-interaction but also to identify causes of interactional problems. Using CA, learners can also reflect on their own interactional practices, including problematic interactional experiences (Clifton, 2011).

CA has inspired a steadily growing body of research in L2 learning and teaching in the West (Barraja-Rohan, 2011; Gardner, 2012; Kasper, 2006, Mori, 2007; Seedhouse, 2004; Sert, 2010; Sert \& Seedhouse, 2011). However, in the East, particularly in the Thai ELT context, there has been a gradual emergence of 'applied-CA' or 'CA-like' studies (see, e.g., Choopool \& Sinwongsuwat, 2017; Chotirat \& Sinwongsuwat, 2011; Makeh \& Sinwongsuwat, 2014; Naksevee \& Sinwongsuwat, 2013; Nookam \& Sinwongsuwat, 2010; Pitaksuksan \& Sinwongsuwat, 2019; Rodpradit \& Singwongsuwat, 2012; Sinwongsuwat, Nicoletti, \& Teng, 2018; Sitthikoson \& Sinwongsuwat, 2017; Teng \& Sinwongsuwat, 2015ab; Ussama \& Singwongsuwat, 2014; Waedaoh \& Sinwongsuwat, 2018). These studies have stressed the importance of turning towards features of naturally-occurring talk, principally those unveiled through CA, when teaching and assessing Thai EFL learners' English conversational skills. Non-scripted role-plays were especially promoted as they reportedly better approximate naturally-occurring conversation and provide students with greater opportunities to practice relevant language features in genuine conversation. Utilizing a CA lens, these studies demonstrated that participation in role-plays of this type could improve both high- and low-proficiency students' conversational skills.

Additionally, more recent studies conducted in a Thai context have provided encouraging findings that students receiving explicit CA-informed instruction interactionally outperformed those who did not. The students who received the CA-informed instruction reported a high level of satisfaction with the new conversation teaching approach, maintaining that it not only helped raise their awareness of the genuine nature and norms of ordinary conversation, but made them feel more confident in speaking and more adept at participating in English conversation (Sinwongsuwat, Nicoletti, \& Teng, 2018; Sitthikoson \& Sinwongsuwat, 2017; Teng \& 
Sinwongsuwat, 2015b; Waedaoh \& Sinwongsuwat, 2018).

\subsection{CA-T Model and Purposes of Current Study}

The encouraging findings from CA-informed studies reviewed in the previous sections of this paper led the authors to propose a blueprint for CA-informed English conversation teaching to Thai EFL learners, referred to as the CA-T model. The model includes the following key features for teachers developing an English conversation lesson: 1) the lesson is interactional goal- and action-driven, making explicit to learners the main goal of the conversation taught and sequential actions to perform to accomplish the goal; 2) the target language, both verbal and nonverbal, is introduced through the appropriate construction of turns to perform these actions in a variety of interactional contexts; 3) learners are exposed to recorded, non-scripted naturally occurring or near-natural talk by English speakers; 4) conversation mechanisms and structure are inductively and deductively taught via an approximant or a CA-informed representation of the recorded talk; 5) emphasis is placed on scaffolded practice of natural conversation via short manageable sequences and non-scripted role-plays; 6) assessments of conversation practice are benchmarked with natural conversation (see Appendix A for a sample rubric); and 7) peer coaching and support are given, especially to help teachers overcome challenges related to conversation analysis.

Since related studies in Thailand have predominately been conducted in tertiary education contexts and only a handful of English teachers have been introduced to CA concepts, this study aimed to explore the benefits of introducing the CA-T model to a wider group of teachers working with younger learners over a long period of time. The ultimate goal is to help raise Thai teachers' awareness of the nature of what they teach and equip them with more effective strategies for teaching students how to successfully participate in English conversations. With this in mind, in the first phase of the research, schoolteachers were engaged in exploring the key elements of the CA-T model through the co-development of lesson plans with the researchers. The aim was to (1) help the teachers develop an understanding of CA and its fundamental concepts, (2) see the potential instructional value of these concepts, and (3) use this knowledge to develop CA-T model conversation lessons for their students. These lessons would be piloted in the teacher participants' classrooms, with each teacher providing implementation feedback which would strengthen the model and improve its feasibility in developing younger EFL learners'English conversation skills.

\section{Method}

\subsection{Participants}

Participants were 16 local school teachers from two Education Service Area Offices in lower southern Thailand. Six of the teachers were from Secondary Education Service Area Office 15 and 10 from Primary Education Service Area Office 2. The teachers volunteered to participate in the longitudinal research with permission from their supervisors. All of the teachers taught English to Matthayom 1-3 (Grades 7-9) students; four also taught Matthayom 4 (Grade 10). The teachers reported spending an average of 14 hours per week teaching English to their students, with three of these hours focused on teaching English conversation skills. The teachers stated that the time spent on teaching conversation was inadequate, and that it usually occurred at the end of the class when students were less attentive. The teachers also stated that students had problems with word recognition and pronunciation, appeared to lack the motivation and confidence to speak English, and were used to rote learning of conversation. By joining the research project, the teachers stated that they hoped to develop new conversational teaching strategies that could address some of the aforementioned teaching and learning challenges. The teachers also expressed a hope that their own English skills would improve as a result of their participation in the project.

\subsection{Procedures}

Funded by the Thailand research fund of the integrated research and innovation type with the project ID LIA6201041S, the longitudinal research was part of an umbrella project aimed at helping Thai youth in lower southern Thailand to acquire $21^{\text {st }}$ century skills, including communication skills, through a holistic and sustainable approach. To realize the creation and implementation of the CA-T model in schools in the focal area, an official invitation letter was sent to English teachers in the area via two education supervisors overseeing Education Service Area Offices (ESAO) 2 and 15, purposively chosen for the project. The letter described the research in detail and outlined its goals and short- and long-term plans. Sixteen teachers from thirteen schools volunteered to participate in the longitudinal project; nine of the teachers were affiliated with ESAO 2 and four teachers with ESAO 15. The teachers were each asked to sign a consent form after receiving a comprehensive explanation of the research goals and plans. 


\subsection{Six-Day Intensive Workshop}

In the summer of 2019, the teachers participated in a 6-day workshop. On Day 1, the researchers and teacher participants were engaged in an ice-breaking activity to learn the names of each of the participants and to become acquainted with one another. The group formed a large circle and the first participant told the group his/her name before the next person repeated the name and added his/her own. This was done in several rounds to ensure that everyone could remember each participant's name.

After the name game, students were put into dyads and ask to recall the last time they had a conversation in English and to describe that experience to their partner. They were asked to describe what happened in the conversation they had had, how successful they felt they had been, and what they had found challenging. These experiences were then shared with the entire group. Each participant reported an experience they deemed to be "unsuccessful", with many citing difficulties understanding different varieties of English and all sharing their inability to overcome feelings of intimidation when conversing with native speakers. Each teacher attributed much of their struggles in communication to their limited exposure to English in their everyday lives.

Next, the teachers were given an orientation outlining the objectives of the project, the rationale behind it, and the expected outcomes. The teachers were asked to agree to helping develop the CA-T model, designing and implementing a pilot CA-T model lesson in their classrooms and assessing the effectiveness of the model lesson.

On Day 2, the teachers were introduced to the theoretical underpinnings of the CA-T model. They studied the importance of talk and language in talk. They were made aware of different meanings of the term grammar as well as traditional and modern approaches to grammar teaching. Through the use of numerous examples, the teachers were asked to identify the differences between written and spoken language, as well as their contrastive features. The sociological concept of conversation was explored, along with the development of Conversation Analysis (CA) and its potential use as a tool to unpack natural conversation so as to understand how language is used and shaped by it. CA principles and its method of analysis were explained along with the necessity of broad and narrow conversation transcription. During the second half of the day, the teachers were shown video clips of English speakers' conversations and, using what they had learned, asked to identify the turn-taking system, including key properties of turns, as well as turn construction and allocation.

On Day 3 and 4, the teachers became familiar with conversation mechanisms such as sequential organization of conversation, conversation structure, repair and overlap. Watching a video clip of English conversations, the teachers were asked to specify the main goal that talk participants were attempting to accomplish in the conversation, identify the turns that allowed them to do so, describe how these turns were organized and connected to the other turns, and identify actions achieved in the turns before and after the non/realization of the main goal. Teachers were explicitly introduced to concepts such as adjacency-pair sequences, sequence-closing thirds, sequence expansions, minimal and non-minimal expansions, overall structure of conversation, as well as topic initiation, pursuit, shift, and termination in conversation. In addition, the teachers were made aware of corpora of naturally occurring English conversations available online such as Santa Barbara Corpus of Spoken American English and introduced to repair mechanisms via a sample conversation taken from the corpora. They were asked to think about whether NSs also have problems when they speak, find evidence in the talk to support their answers, and discuss how the problems are spotted and fixed by talk participants. In particular, teachers were introduced to concepts such as repair, repair processes, types of repair, and repair techniques. Finally, they were made aware of the differences between overlap and interruption as well as different types of overlap in talk.

In addition to exploring an online platform created to provide peer support and to disseminate information related to the project, on Days 5 and 6, the teachers were asked to take what they had learned about CA and to design a CA-T model lesson plan. Before doing so, teachers engaged in an activity designed to provoke discussion about what one should take into consideration when designing a language lesson. To this end, slips of paper were distributed to half the teachers that contained one of the following phrases: objective-driven, activate students' schema, challenging but doable, engaging and fun, safe-learning environment, active learning, sufficient support/scaffolding, and relatable to the students'lives. Next, the remaining teachers were given slips of paper containing examples of the aforementioned phrases/terms. Teachers were then asked to get up and talk with others with the goal of finding a partner whose paper was a match for their own. Once they found their matches, teachers discussed their papers with their partner and took turns sharing what they had with the large group. Teachers were then given an opportunity to discuss, challenge and question the concepts introduced in the matching activity. Following the activity, the teachers were given time to examine the oral English language objectives prescribed by the Thai government and discuss how they would insure that these objectives were met in the lesson they designed. Finally, teachers, working with a small group of others who taught at the same grade 
level, were asked to prepare their first CA-T model lesson plan, taking the following key tenets of the model into consideration:

1) interactional goal/action-driven, focusing on how we get things we want to get done through talk;

2) interactional-context-based teaching of vocabulary and grammatical expressions, focusing not only on meanings but their different uses to perform functions in various interactional contexts;

3) natural or near-natural talk and its representation, used as teaching and learning models;

4) inductively and deductively raising awareness of conversation mechanism, structure and language in conversation via a CA-informed representation of the talk

5) emphasis on manageable, sequential conversation practice and non-scripted roleplay;

6) authentic teacher-, peer-, and self-assessment of conversation practice, benchmarked with natural conversation (see a sample rubric in Appendix A)

7) availability of coaching and peer support

To guide their planning, and assist teachers in remaining mindful of best practices, teachers were given a lesson plan template. A copy of this template can be found in Appendix B.

After completing their lesson plans, teachers volunteered to teach their lesson to the group. After doing so, the researchers and teachers provided feedback, with the researchers using this opportunity to reinforce what had been learned and offer suggestions for how to strengthen the lessons. Additionally, time was allotted for individual teachers to consult with the researchers about the lessons they had created.

\section{Findings and Discussion}

\subsection{CA-T Model Lesson Plan Implementation and Feedback}

After the workshop, and utilizing the online peer group forum designed to provide ongoing support, the teachers developed and implemented their own CA-T lesson plans. An example of a lesson plan created by one of the teacher participants is provided in Appendix C. Approximately four months after the workshop, the teachers participated in a follow-up one-day workshop designed to determine teachers' future commitment to the long-term project and to give teachers an opportunity to provide feedback on the CA-T model lessons.

At the start of the workshop, the teachers engaged in a short activity designed to determine their levels of understanding of CA and the CA-T model. The teachers were asked to recall the core features of CA-T model lessons and describe the differences between these lessons and those they had taught prior to their involvement in the project. The teachers stated that they believed the CA-T model lessons to help their students understand the purpose of a conversation, the relationship between speakers, and the mechanisms at play in the conversation. The teachers also shared that understanding what each speaker is trying to get done through turns at talk would help them demystify what they would need to do themselves when engaged in an English conversation. By using natural or near natural conversation materials from authentic sources such as YouTube, sitcoms, and TV shows, they concurred that the students would be able to acquire useful expressions that would allow them to converse more appropriately and naturally. Students, the teachers argued, would also understand the important roles of pitch, stress, intonation, body language and even silence, when constructing turns. As a result, it would allow them to better express their feelings and emotions. By engaging students in CA-T lessons, the teachers expressed confidence that students would now be able to recognize when to take and yield turns and to understand how a conversation is sequentially organized. The teachers deemed the opportunity for students to participate in frequent scaffolded practice of a conversation in short manageable sequences as valuable, particularly when followed by participation in unscripted role-plays. The students, the teachers remarked, would gain more speaking confidence and would eventually be able to initiate a conversation without any support.

Subsequently, the teachers were each asked to provide more in-depth feedback on their CA-T lesson implementation experiences by reflecting, in writing, on each part of the lesson. They were asked to comment on what worked and what did not, as well as their perception of students' performance and participation in the lesson. Later, they were asked to form small groups, share their comments with group members and then report what they had discussed with the larger group. The teachers' feedback in the group discussions and presentations is outlined below.

\subsubsection{Warm-Up/Activating Schema}

Teachers reported that the beginning of the class, it was often challenging to engage students in participating. Therefore, teachers had to create fun, age-appropriate warm-up activities using flashcards, games, and songs and 
frequently needed to reward students for their participation. The teachers stressed the importance of creating classroom and school environments that arouse the students' interest in learning and that promote their use of English.

\subsubsection{Presentation}

Students were of mixed ability and those with lower levels of English competence often presented negative attitudes towards learning English and participating in the activities. The model conversations the teachers used in their lessons also proved problematic for students who struggled with English literacy. These students needed more assistance to complete tasks; therefore, the teachers stressed the need to choose written materials that better aligned with students' literacy levels. To address this issue during their CA-T lesson, teachers employed a variety of activities such as having students put scrambled turns into logical conversation sequences and repeat those turns after the teacher. Low and high proficiency students were grouped together, so that the latter could provide support to the former. Teachers used online resources such as YouTube videos, but this was often unsuccessful as most schools are located in remote areas where unstable Internet connections make using such resources challenging. In addition to needing a more reliable Internet connection, the teachers felt that the classrooms were in need of good quality TV screens and speakers to make the CA-T lesson more successful.

\subsubsection{Practice}

Given students' literacy problems and lack of confidence in general, the teachers posited that after explaining the model conversation to the students, it was extremely helpful, following the CA-T model, to have students practice the conversations in a short meaningful sequence. Visual scaffolding in the form of cards posted around the classroom containing targeted language also proved beneficial, as did varying the pairing and groups based on the linguistic strengths and weaknesses of the students.

\subsubsection{Production and Performance Assessment}

The teachers reported that students had great difficulty participating in non-scripted role-plays, citing students' limited vocabulary, and relying too heavily on scripts that were provided as examples. To address this, teachers introduced additional video clips chosen to make students aware of the range of language choices available. Only after viewing and discussing many clips, were the students able to produce their own unscripted role-plays. Frequent exposure to video materials of natural or near natural English conversation was also necessary to motivate the students and bolster their confidence in their ability to create their own unscripted role-plays. As far as the assessment of the students ' conversational performance is concerned, none of the teachers mentioned the use of the assessment rubric briefly introduced in the workshop. Apparently, relying mainly on their perception and summative assessment, the teacher needed more time and training to feel comfortable to manipulate the rubric proposed in assessing their students 'performance.

\subsubsection{Wrap-Up/Closing}

During the wrap-up/closing portion of the lessons, teachers asked students to summarize what they had learned in the lesson. Students were often reluctant to speak and participation was generally limited to the talkative and more competent English learners. As a result, the teachers felt this part of the lesson was unsuccessful. Brainstorming with the group, the teachers decided to use exit tickets (something they had learned about and used during the 6-day workshop) in future classes. The group agreed that providing students with time to pose questions and/or comment on the lesson in writing might provide some of the needed feedback the teachers were seeking and in a less threatening manner.

\subsection{Online Coaching/Peer Support and Benefits of CA-T Model Lessons}

While the teachers were interested in using the online coaching and peer support platform set up for them, many expressed a need for more training in using the platform. The teachers suggested using such platforms as Facebook. Additionally, the teachers were unfamiliar with the concept of peer coaching and reported being reluctant to comment on their peer's work.

Overall, when asked what they perceived to be the benefits of the CA-T model, the teachers unanimously agreed that the CA-T lessons had helped their students became more aware of features of conversational language and less worried about having to speak in full sentences. Students reported that they were able to speak more confidently and naturally and demonstrated better manipulation of prosodic resources. As the students were engaged in analyzing a model conversation, CA-T lessons helped them better understand English conversations in different contexts, thereby assisting them in creating simple English conversations on their own. The CA-T lessons offered students (and teachers) a new and more interesting way to learn English conversation. And, as a result, teachers reported that students were more actively engaging in the English conversations. 
Nevertheless, to implement CA-T lessons successfully, certain challenges need to be overcome. The teachers argued that technological affordances are the key and that the lessons are more suitable for students with higher levels of English literacy and those able to construct simple turns in English. For students with low levels of literacy, at least at the initial stage, teachers may need to focus solely on speaking and getting the students to simply make sense of what they hear, turn by turn, and not rely on written text. In fact, one of the teachers reported that students with low literacy levels were inclined to be more creative and converse more freely than peers with higher literacy levels, as the latter tended to worry about perfecting their conversation according to the script. In terms of needs and support for an effective full-scale implementation of CA-T lessons in the future, the teachers suggested that it would save them a lot of time if detailed manuals could be provided along with CA-T model English conversation textbooks that match students' levels.

\section{Conclusion}

Applying insights from Conversation Analysis (CA) and CA studies to enhance the efficacy of English conversation teaching in Thai schools, this paper reports on Phase 1 of a study aimed at developing and piloting a viable CA-T teaching model. To this end, local primary and secondary teachers engaged in a CA-T model training workshop designed to help the teachers (and, ultimately, their students) understand the natural mechanisms and purposes of conversation, recognize the role and importance of turn-taking in a conversation, identify the linguistic and nonlinguistic resources employed in constructing turns, and be cognizant of and more adept at organizing one's talk. Additionally, teachers were given opportunities to examine the motivational value of learning the target language with a variety of natural or near natural conversation materials and the instructional benefits of using non-scripted role-plays.

Working with the authors, teachers created lessons that: 1) were interactional goal/action-driven, and context-based, 2) utilized recorded natural or near-natural talk and its representation, 3) included activities in which students were asked to inductively and deductively identify conversation mechanisms and language structures found in conversation, 4) focused on manageable sequential conversation practice, 5) engaged students in non-scripted roleplays, 6) employed natural conversation-benchmarked assessments of conversation practice, and 7) provided peer coaching and support.

After implementing the lessons, teachers provided encouraging feedback. There was consensus among the teachers that their students were more engaged in the CA-T lessons than they had been in previous lessons. Students, the teachers reported, shared that they felt more confident participating in the non-scripted role-plays and that they enjoyed the activity. The teachers attributed this newfound confidence to the explicit CA lessons teachers had provided before the role-play activities. While all the teachers were encouraged by these initial findings, they expressed a need for more professional development, stating that the 6-day workshop and ongoing peer support, while excellent, did not provide them with the level of support that they needed to continue independently. The teachers suggested the creation of a CA-T model English conversation textbook with a teacher's manual and a user-friendly online platform where they could access more professional and peer support. The teachers also shared a frustration with the lack of time and resources needed to locate appropriate video examples of natural or near natural English conversation and asked that recommendations for appropriate videos be provided in the textbook. Moreover, teachers expressed an interest in participating in more professional development workshops so as to develop a more comprehensive understanding of CA, learning how to more accurately and effectively evaluate and assess students' conversation skills, and in sharing and developing new strategies for grouping students and better scaffolding their learning.

The results of Phase 1 of this study are promising. They point to the feasibility and value of introducing teachers to the CA-T model and provide the researchers with feedback on how to improve the model. Additionally, the results suggest the need for a textbook that can provide teachers and students with the resources and support they will need to gain the greatest benefits from the model.

\section{Acknowledgments}

This paper emanates from a longitudinal research project, ID LIA6201041S, supported by the Thailand Research Fund. The project is part of a larger research and innovation program aimed at helping Thai youth in lower southern Thailand to acquire 21st century skills through a holistic and sustainable approach. The authors owed a debt of gratitude towards the Research and Development Office, Prince of Songkla University, the program manager, Associate Professor Kasetchai Lae-heem, and the other members of the research team including Kornsak Tantiwich, Abdulloh Waedaoh, and David Allen Bruner. Our thanks were also extended to our M. A. TEIL students, Martin James Farrelly and Nasree Pitaksuksan, and especially to all the educational supervisors and teachers from Secondary Education Service Area Offices 15 and 2, who enthusiastically partook in our 
CA-T Model workshops.

\section{References}

Aleixo, M. B. (2003). Teachers' perceptions of communicative language teaching use in Brazil. Graduate theses, dissertations, and problem reports, 719. Retrieved from https://researchrepository.wvu.edu/etd/719

Atagi, R. (2011). Secondary teacher policy research in Asia: Second teachers in Thailand. Bangkok. UNESCO Bangkok, 2011. Retrieved from https://unesdoc.unesco.org/ark:/48223/pf0000215102

Baker, W., \& Jarunthawatchai, W. (2017). English language policy in Thailand. European Journal of Language Policy, 9(1), 27-44. https://doi.org/10.3828/ejlp.2017.3

Barraja-Rohan, A. M. (2011). Using conversation analysis in the second language classroom to teach interactional competence. Language Teaching Research, 15(4), 479-507. https://doi.org/10.1177/1362168811412878

Bax, S. (2003). The end of CLT: A context approach to language teaching. English Language Teaching Journal, 57(3), 278-287. https://doi.org/10.1093/elt/57.3.278

Bowles, H. (2006). Bridging the gap between conversation analysis and ESP: An applied study of the opening sequences of NS and NNS service telephone calls. English for Specific Purposes, 25, 332-357. https://doi.org/10.1016/j.esp.2005.03.003

Brown, H. D. (1994). Teaching by principles: An interactive approach and language pedagogy. San Francisco State University, USA: Prentice Hall Regents.

Brown, H. D. (2000). Teaching by principles: An interactive approach and language pedagogy (2nd ed.). New York, NY: Longman.

Bruner, D. A., Shimray, Y. P., \& Sinwongsuwat, K. (2014). Thai-Serbian A2 university EFL learners' perspectives on learning and teaching oral English communication skills. In Pramarn Subphadoongchone (Ed.), The 34th Thailand TESOL International Conference Proceedings 2014 (pp. 13-34). Chiang Mai: TESOL Thailand.

Bruner, D. A., Sinwongsuwat, K., \& Radić-Bojanić, B. (2015). EFL oral communication teaching practices: A close look at university teachers' and A2 students' perspectives in Thailand and a critical eye from Serbia. English Language Teaching, 8(1), 11-20. https://doi.org/10.5539/elt.v8n1p11

Choopool, P., \& Sinwongsuwat, K. (2017). Effectiveness of Form-Focused Repairs in Improving Low-Proficiency Learners' Speaking Performance. Veridian E-Journal, 10(4), 458-472.

Chotirat, S., \& Sinwongsuwat, K. (2011, April 2). Effects of scripted and non-scripted role play activities on oral performance: A case study of repair organization in conversation of Thai college students [Paper presentation]. The 3rd International Conference on Humanities and Social Sciences. Faculty of Liberal Arts, Prince of Songkla University, Thailand.

Clifton, J. (2011). Combining conversation analysis and reflective practice in the ESP classroom: Putting transcripts of business simulations under the microscope. J. Clifton/Scripta Manent, 6(1-2), 25-34.

Couper-Kuhlen, E., \& Selting, M. (2001). Introducing interactional linguistics. https://doi.org/10.1075/sidag.10

Darasawang, P. (2007). English language teaching and education in Thailand. A decade of change in N. D. Prescott (Eds.), English in Southeast Asia: Varieties, literacies and literatures (pp. 187-204). Cambridge, UK: Cambridge Scholars Publishing.

Duranti, A. (1997). Linguistic anthropology. Cambridge, UK: Cambridge University. Press. https://doi.org/10.1017/CBO9780511810190

Educational Testing Service (ETS). (2017). Test and score data summary for TOEFL iBT® Tests: January 2016-December 2016 Test Data. Retrieved from https://www.ets.org/s/toefl/pdf/94227_unlweb.pdf

EF Education First. (2019). The world's largest ranking of countries and regions by English skills (9th ed.). Retrieved from https://www.ef.com/wwen/epi/

Fredrickson, T. (2015, November 6). Thailand's English skills lagging, says training company. Bangkok Post. Retrieved

from https://m.bangkokpost.com/learning/advanced/756536/thai-english-proficiency-drops-now-3rd-worst-in-asi a-ef 
Fujii, Y. (2012). Raising awareness of interactional practices in L2 conversations: Insights from conversation analysis. International Journal of Language Studies, 6(3), 99-126.

Gardner, R. (2012). Conversation Analysis and orientation to learning. Journal of Applied Linguistics, 5. https://doi.org/10.1558/japl.v5i3.229

Have, P. ten. (2007). Doing conversation analysis (2nd ed.). London, UK: SAGE. https://doi.org/10.4135/9781849208895

Hayes, D. (2010). Language learning, teaching and educational reform in rural Thailand: An English teacher's perspective. Asia Pacific Journal of Education, 30(3), 305-319. https://doi.org/10.1080/02188791.2010.495843

Heap, J. (1997). Conversation analysis methods in researching language and education. In N. H. Hornberger \& D. Corson (Eds.), Encyclopedia of language and education. Vol. 8: Research methods in language and education (pp. 217-225). Dordrecht/Boston/London: Kluwer Academic Publishers. https://doi.org/10.1007/978-94-011-4535-0_21

Heritage, J. (1984). A change-of-state token and aspects of its sequential placement. In J. M. Atkinson \& J. Heritage (Eds.), Structures of social action: Studies in conversation analysis (pp. 299-345). Cambridge: Cambridge University Press. https://doi.org/10.1017/CBO9780511665868.020

Hutchby, I., \& Woofit, R. (1998). Conversation Analysis. Malden, MA: Blackwell Publishers Inc.

Kasper, G. (2006). Beyond repair: Conversation analysis as an approach to SLA. AILA Review, 19, 83-99. https://doi.org/10.1075/aila.19.07kas

Khamkhien, A. (2010). Teaching English speaking and English speaking tests in the Thai context: A reflection from Thai perspective. English Language Teaching, 3(1), 184-190. https://doi.org/10.5539/elt.v3n1p184

Kindell, J., Keady, J., Sage, K., \& Wilkinson, R. (2017). Everyday conversation in dementia: a review of the literature to inform research and practice. International journal of language \& communication disorders, 52(4), 392-406. https://doi.org/10.1111/1460-6984.12298

Kirkpatrick, R., \& Ghaemi, H. (2011). Beyond the communicative approach in language teaching. Modern Journal of Language Teaching Methods, 1(3), 143-139.

Koshik, I, Jacoby, S., Olsher, D., \& Schegloff, E. A. (2002), Conversation analysis and applied linguistics. Annual Review of Applied Linguistics, 22(3), 3-31.

Kramsch, C. (2014). Teaching foreign languages in an era of globalization: Introduction. The Modern Language Journal, 98(1), 296-311. https://doi.org/10.1111/j.1540-4781.2014.12057.x

Kustati, M. (2013). The shifting paradigms in the implementation of CLT in Southeast Asia countries. https://doi.org/10.15548/jt.v20i1.23

Kwangsawad, T., \& Yawongsa, P. (2009). Bridging the gap between CLT and CBI theory and practice. Retrieved from https://www.yumpu.com/.../bridging-the-gap-between-clt-and-cbi-theory

Larsen-Freeman, D. (1986). Techniques and principles in language teaching. New York, NY: Oxford University Press.

Liddicoat, A. J. (2007). An introduction to conversation analysis. London: Continuum.

Makeh, A., \& Sinwongsuwat, K. (2014, May). Improving and retaining oral English performance with scripted role-play: A study of Thai primary school students. International Proceedings of L-SA Workshops \& Colloquium 2014 Faculty of Liberal Arts, Prince of Songkla University, Hat Yai, Thailand.

Mala, D. (2016, Jan 2). Thais fear AC English barrier. Bangkok Post. Retrieved from http://www.bangkokpost.com/learning/learning-news/813852/asean-community-challenges-thai-english-ski $11 \mathrm{~s}$

Mala, D. (2019, April 4). Obec brands O-Net fails a success. Bangkok Post. Retrieved from https://www.bangkokpost.com/thailand/general/1656204/obec-brands-o-net-fails-a-success

Methitam, P., \& Chamcharatsri, P. B. (2011). Critiquing ELT in Thailand: A reflection from history to practice. Journal of Humanities, Naresuan University, 8(2), 57-68.

Mori, J. (2007). Border crossing: Exploring the intersection of second language acquisition, conversation analysis and foreign language pedagogy. The Modern Language Journal, 91, 849-862. 
https://doi.org/10.1111/j.0026-7902.2007.00673.x

Naksevee, N., \& Sinwongsuwat, K (2013, May). Using non-scripted role-play to teach speaking skills: A study of English conversation of Thai college students at Yala Rajbhat University. The 11th International Conference on Developing Real-Life Learning Experience (DRLE 2013): Learning Innovation for ASEAN (p36-1-p36-9). King Mongkut's Institute of Technology Ladkrabang, Bangkok, Thailand.

Nation. (2017). Mathayom 6 students struggle in O-Net test. Retrieved from http://www.nationmultimedia.com/news/national/30307964

Nookam, W., \& Sinwongsuwat, K. (2010). Thai EFL learners' use of 'discourse markers' in English Conversation: A study of business English students at Didyasarin International College. In J. L. Bueno Alonso et al. (Eds.), 2010 Analizar datos $>$ Describir variación/Analysing data $>$ Describing variation (pp.285-298). Vigo: Universidade de Vigo (Servizo de Publicacións).

Noom-ura, S. (2013). English teaching problems in Thailand and Thai teachers' professional development needs. English Language Teaching, 6(11), 139-147. http://doi.org/10.5539/elt.v6n11p139

Pitaksuksan, N., \& Sinwongsuwat, K. (2019, November). CA-informed analysis of English conversations in Thai high school textbooks. Proceedings of 207th IASTEM International Conference (pp. 23-27). Oxford, UK: IASTEM.

Pourhaji, M., \& Alavi, S. M. (2015). Identification and distribution of interactional contexts in EFL classes: The effect of two contextual factors. Journal of English Language Teaching and Learning, 7(15), 93-123.

Prapphal, K. (2001). Globalization through distance education via Inter- and Intranet pedagogy. PASAA, 31, 75-81.

Psathas, G. (1995). Conversation analysis: The study of talk-in-interaction. London: Sage Publications, Inc. https://doi.org/10.4135/9781412983792

Ramadan, M. (2017, October 29). Seven kinds of CLT activities to build up students' communicative competence. English Language Teaching and Testing Guide. Retrieved from https://elttguide.com/seven-kinds-of-clt-activities-to-build-up-students-communicative-competence/

Richards, J. C. (2006). Communicative language teaching today. New York, NY: Cambridge University Press.

Richards, J. C., \& Rodgers, T. (2001). Approaches and methods in language teaching (2nd ed.). Cambridge, UK: Cambridge University. https://doi.org/10.1017/CBO9780511667305

Rodpradit, S., \& Sinwongsuwat, K. (2012). Using scripted and non-scripted role-plays to improve English speaking performance of hotel engineering staff. APHEIT Journal, 18(1), 17-25.

Sacks, H. (1995). Lectures on Conversation. Oxford: Blackwell. https://doi.org/10.1002/97814444328301

Sacks, H., Schegloff, E. A., \& Jefferson, G. (1974). A simplest systematics for the organization of turn-taking for conversation. Language, 50, 696-735. https://doi.org/10.2307/412243

Saengboon, S. (2002). Beliefs of Thai teachers about communicative language teaching. (Unpublished doctoral dissertation). Indiana University Bloomington, USA.

Schegloff, E. A., \& Sacks, H. (1973). Opening up closings. Semiotica, 8, 289-327. https://doi.org/10.1515/semi.1973.8.4.289

Seedhouse, P. (2004). The interactional architecture of language classroom: A conversation analysis perspective. Oxford, UK: Blackwell.

Seedhouse, P. (2005). Conversation analysis and language learning. Language Teaching, 38(4), 165-187. https://doi.org/10.1017/S0261444805003010

Seedhouse, P. (2008). Learning to talk the talk: Conversation Analysis as a tool for induction of trainee teachers. In Garton, S. \& Richards, K. (Eds.), Professional Encounters in TESOL (pp. 42-57). Basingstoke: Palgrave Macmillan. https://doi.org/10.1057/9780230594173_3

Sert, O, \& Seedhouse, P. (2011). Introduction: Conversation Analysis in Applied Linguistics. Novitas-ROYAL (Research on Youth and Language), 5(1), 1-14.

Sert, O. (2010). A proposal for a CA-integrated English language teacher education program in Turkey. Asian EFL Journal, 12(3), 62-97.

Sidnell, J. (2010). Conversation Analysis: An introduction. Malden, MA: Wiley-Blackwell. 
Sidnell, J., \& Stivers, T. (2012). The handbook of conversation analysis. Malden, MA: Wiley-Blackwell. https://doi.org/10.1002/9781118325001

Sinwongsuwat, K., Nicoletti, K., \& Teng, B. (2018). CA-informed conversation teaching: Helping Thai students unpack English conversation to become conversationally competent. The Journal of Asia TEFL, 15(3), 700-720. https://doi.org/10.18823/asiatefl.2018.15.3.9.700

Sitthikoson, A., \& Sinwongsuwat, K. (2017). Effectiveness of CA-informed telephone conversation instruction in enhancing conversation abilities of Thai learners of English. Veridian E-Journal, 10(4), 63-85.

Sun, D. (2014). From communicative competence to interactional competence: A New Outlook to the Teaching of Spoken English. Journal of Language Teaching and Research, 5(5), 1062-1070. https://doi.org/10.4304/j1tr.5.5.1062-1070

Teng, B., \& Sinwongsuwat, K. (2015a). Teaching and learning English in Thailand and the integration of Conversation Analysis (CA) into the classroom. English Language Teaching, 8(3), 13-23. http://doi.org/10.5539/elt.v8n3p13

Teng, B., \& Sinwongsuwat, K. (2015b). Improving English conversation skill through explicit CA-informed instruction: A study of Thai university students. PASAA Paritat Journal, 30, 65-104.

Thai Library Integrated System (ThaiLIS). (2017). ThaiLIS Digital Collection Working Group. [Database record]. Retrieved from https://www.thailis.or.th/tdc/

Ussama, R., \& Sinwongsuwat, K. (2014). Conversation proficiency assessment: A comparative study of two-party peer interaction and interview interaction implemented with Thai EFL. International Journal of Language Studies, 8(4), 95-106.

Waedaoh, A., \& Sinwongsuwat K. (2018). Enhancing English language learners' conversation abilities via CA-informed sitcom lessons. English Language Teaching, 11(12), 121-130. https://doi.org/10.5539/elt.v11n12p121

Wong, J., \& Waring, H. Z. (2010). Conversation analysis and second language pedagogy. London, UK: Taylor \& Francis. https://doi.org/10.4324/9780203852347

Wu, Y. (2013). Conversation Analysis: A discourse approach to teaching oral English skills. International Education studies, 6(5), 87-91. https://doi.org/10.5539/ies.v6n5p87

Young, R. (1999). Sociolinguistic approaches to SLA. Annual Review of Applied Linguistics, 19, $105-132$. https://doi.org/10.1017/S0267190599190068 


\section{Appendix A}

\section{Roleplay Evaluation Rubric}

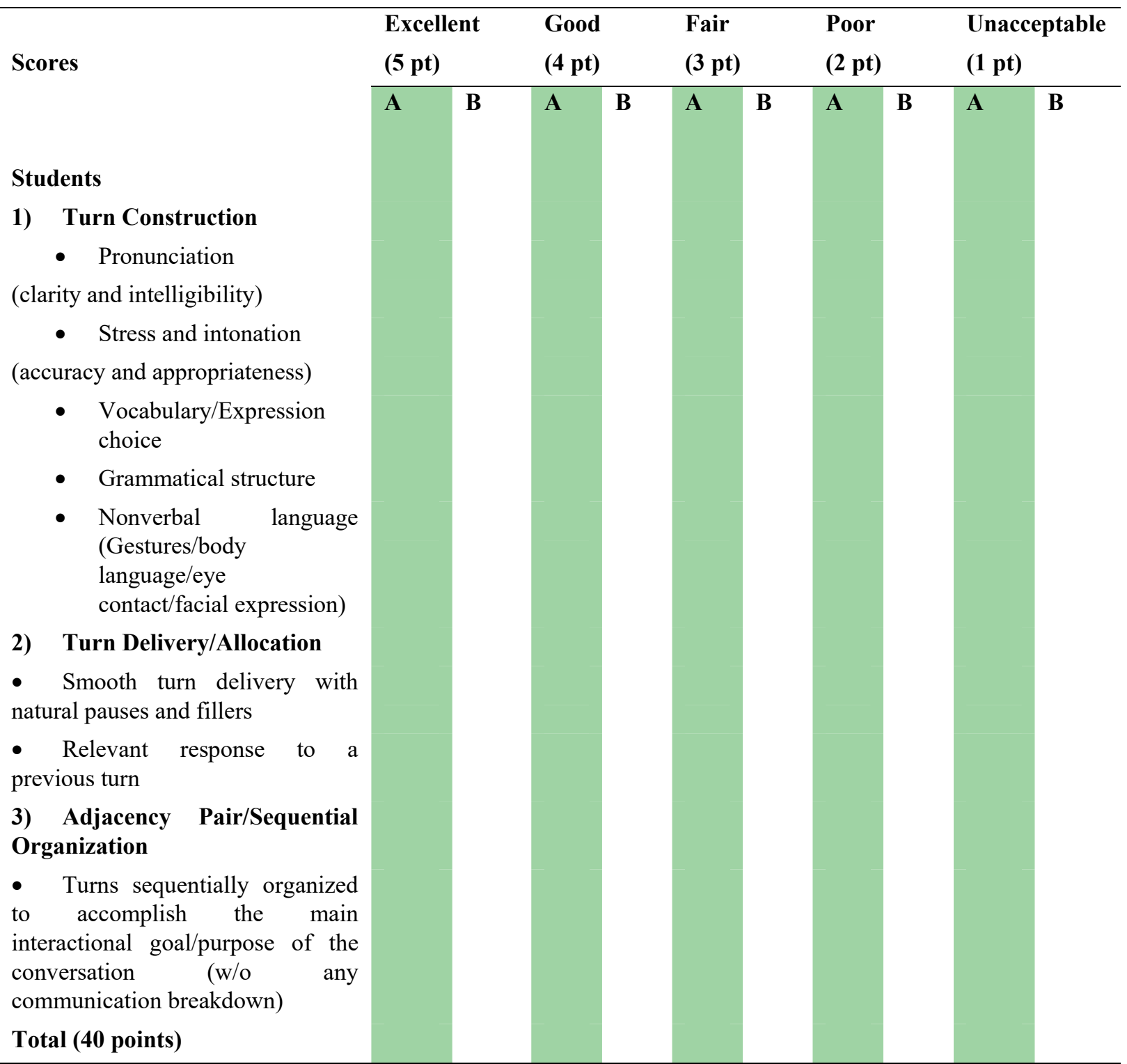




\section{Appendix B}

Lesson Plan Template

\section{Lesson Topic}

[Subject]

[Grade Level]

[Class Dates]

Objectives:

Materials Needed

Government Language Objective(s):

CA-T Learning Objective (s):

Target Language Nocabulary

Homework/Additional

Assignments

Detailed Description of Activities

Activating Schema (Time Needed: )

Activity 1 (Time Needed )

Activity 2 (Time Needed:

Activity 3 (Time Needed

Closing Activity (Time Needed:

Evaluation Plan 


\section{Appendix C}

\section{Sample Lesson Plan}

Lesson Topic: Greeting

Subject: English (E22101)

Class: Secondary 2

Date: $24^{\text {th }}$ July 2019 (09:11-10:30)

Time: 2 periods (80 minutes)

\section{Objectives}

Government Language Objective

Strand 1: Language for communication

F2.1 S2/1 Use language, tone of voice, gestures and manners appropriate to various persons and occasions by observing social manners of native speakers.

CA-T Learning objectives

1. Understand the purpose and mechanism of conversations.

2. Identify and carry out adjacency-pair sequences of greetings.

Target Language/ Vocabulary

\section{Material Needed}

greeting, introduction, intonation, gesture, pronunciation

Video clip - https://www.youtube.com/watch?v=mHuoOXiHvM4

$\underline{\text { Homework/ Additional Assignment }}$ -

\section{Detailed Description of Activities}

Activating Schema (10 minutes)

Song "nice to meet you"

Activity 1 - Presentation (20 minutes)

1. Play the video clip (2-3 rounds) and students highlight the new vocabulary, phrases or sentences.

2. Discuss and explain about the conversation to make students understand the main goal of the conversation.

3. Identify the goal of conversation in each pair.

4. Analyze the function of turns (sequences of adjacency pair)

Activity 2 - Practice (20 minutes)

1. Practice the pronunciation and intonation. (play the video clip and students repeat after the clip)

2. Pair work- students practice the conversation based on the script.

Activity 3 - Production (20 minutes)

1. Pair work - students create their own conversation (Using their own information in the conversation)

2. Randomly choose some pairs for non-scripted role play in front of the class/ assign some students to give feedback on their friends' presentation

Closing Activity - Wrap up (10 minutes)

from the video.

Conclude the lesson about greeting by playing the video clip again and students identify what they have learned

\section{Evaluation Plan}

1. Self and peer assessment

2. Assess the students' performance (using an assessment rubric)

\section{Transcription}

From the video - https://www.youtube.com/watch?v=mHuoOXiHvM4 $(0.05-0.12)$

1. Molly:

2. Peter:

Excuse me, ah, $\uparrow$ hello

3. Molly:

4. Peter:

Hi $\uparrow$

My name is Molly What's your name?

5. Molly: My friends call me Molly $\mid($ (laughing)). Hi Pete, It's nice to meet you!

6. Peter: It's nice to meet you, too.'

Teacher: F. Baka, Banbalukaya-ing School, Narathiwat Primary Educational Service Area Office 2

\section{Copyrights}

Copyright for this article is retained by the author(s), with first publication rights granted to the journal.

This is an open-access article distributed under the terms and conditions of the Creative Commons Attribution license (http://creativecommons.org/licenses/by/4.0/). 